\title{
BERIMAN DAN BERDOA KARENA ALLAH SUATU EKSPOSISI LUKAS 18:1-8
}

\author{
STEVRI I. LUMINTANG
}

\section{PENDAHULUAN}

Banyak alasan orang Kristen beriman kepada Tuhan, di antaranya adalah karena Tuhan itu baik, Tuhan itu Juruselamat, karena Tuhan adalah penolong, karena Tuhan adalah mahakuasa, dan lain sebagainya. Semua alasan ini dapat ditemukan dengan muda di buku-buku nyanyian Gereja masa kini, dan pada pernyataan-pernyataan para pengkhotbah dan para pemimpin ibadah kontemporer. Orang beriman bukan karena iman melainkan pada iman plus. Beriman pada sesuatu yang ada pada Allah, yaitu kebaikan Allah, keselamatan Allah, pertolongan Allah dan kuasa Allah, bukan pada Allah. Seperti seorang istri memuji suaminya, bukan karena apa adanya suaminya (ontologis), melainkan karena apa yang ada pada suaminya, sama dengan ungkapan "ada uang abangku sayang, tidak ada uang abang melayang." Ada pertolongan Tuhan, Tuhan ku sayang, tidak ada pertolongan Tuhan, Tuhan melayang.

Beriman tidak dapat dipisahkan dengan berdoa. Berdasarkan filsafat dan psikologi agama, paling sedikit ada dua alasan orang berdoa, yaitu karena adanya kebutuhan dan karena adanya masalah. Yang pertama, doa dijadikan alat untuk memenuhi kebutuhan; sedangkan yang kedua, doa dijadikan media bagi solusi atas masalah apapun. Dalam hal ini, doa menjadi alat untuk memperoleh yang diinginkan dan untuk mengatasi masalah yang dihadapi. Semua kebutuhan dan masalah disampaikan kepada Allah yang dijadikan sebagai objek yang dikendalikan oleh pendoa. Praktik doa seperti ini semakin dipropaganda oleh para pengkhotbah kontemporer yang biasa menyatakan kalimat-kalimat seperti berikut: "Asal kamu yakin apa yang kamu doakan, maka doamu akan terkabul" atau "Kamu harus yakin bahwa apa yang kamu minta itu sudah dijawab, dan bayangkanlah bahwa itu sudah ada." Atau pernyataan ini: "Asal dengan menjamah mobil yang kita inginkan, maka Tuhan pasti memberikan mobil yang sama." Apakah seperti ini doa Kristen? Apakah seperti ini doa yang seharusnya diajarkan oleh Gereja? Apakah seperti ini arti doa menurut Alkitab? Apakah Tuhan objek atau subjek doa? Mari kita mempelajari satu bagian Alkitab mengenai doa, yakni Lukas 18:1-8. 


\section{LATAR BELAKANG INJIL LUKAS}

Injil Lukas adalah Injil yang memiliki karakteristik tersendiri dibandingkan dengan Injil lainnya. Pada umumnya, para ahli berpendapat bahwa Lukas adalah seorang tabib, namun bagi penulis, Lukas bukan hanya seorang tabib, melainkan ia juga adalah seorang sejarahwan, karena ialah yang menulis Injil Lukas dengan menegakkan historitas Tuhan Yesus, demikian dengan kitab sejarahnya yakni Kisah Para Rasul. Dari semua penulis Injil, maka Lukaslah yang terdekat dalam hal penulisan riwayat hidup Tuhan Yesus. Ia menjelaskan kelanjutan pelayanan Tuhan Yesus dengan berdirinya Gereja mula-mula, dan dalam tulisannya Yesus menjadi bagian dari sejarah Gereja.

Perhatian Injil Lukas ialah pada kedatangan era keselamatan yang baru yaitu bersifat universal (universatity of salvation). Keselamatan yang bersifat universal ini ditandai oleh era pekerjaan Roh Kudus, dan terbukanya keselamatan untuk semua orang termasuk non-Yahudi. Keselamatan yang bersifat universal itu dikemukakan oleh Lukas dalam konsep kerajaan Allah, dimana Yesus Kristus adalah manifestasi Kerajaan Allah yang sempurna. Bagian yang khusus dalam pengajaran Tuhan Yesus tentang kerajaan Allah ialah penerimaan dan pemuridan. Orang yang menerima Tuhan Yesus sekaligus menjadi anggota kerajaan Allah, melalui proses pemuridan. Salah satu tema pemuridan adalah beriman dan berdoa.

Secara khusus, Lukas mencatat satu perumpamaan Tuhan Yesus yang mengetengahkan mengenai ketekunan dalam doa sebagai sikap yang benar terhadap kedatangan Anak Manusia dalam konteks eskatologis. Perumpamaan itu yaitu perumpamaan tentang seorang janda yang tekun (Luk 18:1-8). Keistimewaan dari teks perumpamaan ini ialah bahwa perumpamaan ini tidak ada dalam injil-injil yang lain. Dengan kata lain, hanya Lukas-lah yang mencatat tentang perumpamaan Tuhan Yesus ini. Perumpamaan ini adalah sangat menarik untuk dikaji, karena ada beberapa hal yang kelihatannya adalah agak membingungkan, di antaranya, yaitu sikap hakim yang tidak benar namun membenarkan kasus seorang janda. Secara khusus perumpamaan ini semakin menarik untuk dikaji karena hakim yang tidak benar dianalogikan dengan Allah. Karakter hakim dalam perumpamaan ini jelas-jelas bertolak belakang sama sekali dengan karakter Allah; dan motivasi hakim membenarkan janda tersebut adalah berbeda sama sekali dengan motivasi Allah membenarkan atau menjawab doa orang-orang pilihan-Nya. Selain itu, kebenaran teologis dari perumpamaan ini, nampaknya sangat relevan untuk dijadikan acuan untuk menyikapi praktik agamawi yang sedang menjamur masa kini, yaitu praktik yang sama 
kelihatannya antara doa orang-orang Kristen dengan doa orang-orang nonKristen, yaitu giat berdoa demi sesuatu atau segala sesuatu yang diinginkan. Doa dijadikan media untuk memenuhi kebutuhan para pendoa. Seolah-olah doa adalah cara untuk menjadi kaya. Doa juga dijadikan senjata untuk mengusir setan, sehingga hampir tidak terlihat perbedaannya dengan dukun yang mengusir setan dari seseorang yang kerasukan setan. Yang terakhir ini, doa dijadikan alat ukur iman orang beragama. Seolah-olah orang yang banyak berdoa adalah orang beriman.

Sebelum menafsirkan perumpamaan yang terdapat dalam Lukas 18:1-8 mengenai seorang hakim yang tidak benar atau seorang janda yang tekun, maka sangatlah penting untuk menganalisis perumpamaan ini terlebih dahulu, secara khusus menganalisis teks, konteks dan latarbelakangnya.

\section{$\underline{\text { Analisis Teks }}$}

Analisis teks adalah suatu studi untuk memahami hakikat teks tertentu, baik bentuk, gendre dan stuktur teks tersebut supaya dapat menemukan pengertian teks sedekat mungkin dengan maksud penulis.

\section{Bentuk Teks}

Lukas 18:1-8 adalah satu bentuk teks perumpamaan yang disertai dengan penerapan yang mengikat perumpamaan itu. ${ }^{1}$ Perumpamaan ini merupakan salah satu dari sekian banyak perumpamaan Yesus dalam Injil Lukas, khususnya merupakan satu dari tujuh belas perumpamaan yang tergolong dalam Journey Narrative (Luk 9:51-19:27). Perumpamaan ini adalah perumpamaan dari pernyataan Yesus (illustration of statement). Memang kata perumpamaan dalam Perjanjian Baru (PB) adalah memiliki suatu konotasi yang luas. Secara umum, Simon J. Kistemaker membagi perumpamaan-perumpamaan Perjanjian Baru dalam 3 bagian besar, yaitu The true parables, story parables, and illustrations. ${ }^{2}$ Dan Lukas 18:1-8

${ }^{1}$ Bnd. Darrell L. Bock, Luke Volume 2. Baker Exegetical Commentary on the New Testament (Grand Rapids: Baker Book House, 1998 ), 1446.

${ }^{2}$ The True Parables. These use an illustration from daily life within reach who hears the parables.Everyone acknowledges the truth conveyed; there is no basis for any objection or criticism; Story parables Differing from the true parables, the story parables does not rely on an obvious truth or generally custom. The true parables is told in the present tense as fact; Illustration. Illustrative stories appearing in the Gospel of Luke are 
adalah termasuk dalam Kelompok story parables. Artinya perumpamaan mengenai Hakim yang tidak benar atau Janda yang tekun dalam Lukas 18:1-8, adalah satu perumpamaan yang bersifat cerita, dan sekalipun bukan cerita yang benar-benar terjadi atau bukan cerita yang nyata namun cerita ini membawa atau memberikan kebenaran yang penting. ${ }^{3}$ Melalui perumpamaan ini, Tuhan Yesus sedang mengajarkan dalam konteks pemuridan mengenai arti pemuridan dalam konteks kerajaan Allah yang hanya dimengerti jelas oleh pendengar, khususnya para murid-murid Tuhan yang sedang dimuridkan.

\section{Judul Teks Perumpamaan}

Alkitab versi LAI memberikan judul bagi teks Lukas 18:1-8 adalah perumpamaan hakim yang tidak benar. Alkitab versi NGSB dan NIV memberikan judul untuk teks ini adalah perumpamaan tentang Janda yang tekun. ${ }^{4}$ Dari perbandingan di atas, maka nampak perbedaan penekanan, yaitu bahwa LAI menekankan karakter hakim sedangkan NGSB dan NIV menekankan karakter janda. Para penafsir pun adalah berbeda dalam pemberian judul. Herbert Lockyer, Simon J. Kistemaker dan B.J. Boland memberikan judul untuk teks Lukas 18:1-8 adalah Unjust Judge dan Unrighteou Judge. Karakter hakim sebagai sorotan utama. Sedangkan Graig A. Evans serta Darrell L. Bock memberikan judul untuk teks Lukas 18:1-8 adalah The Nagging Widow. Penekanannya pada karakter janda dalam hal memohon atau berdoa dengan tekun. Searah dengan ini juga penafsir lain memberikan judul pembahasan teks ini adalah doa, seperti William Barclay dan Craig A. Evans. Hanya Earle Ellis yang melihat secara bersama-sama kedua karakter dalam teks tersebut. ${ }^{5}$

usually categorized as example stories; Simon J. Kistemaker, The Parables of Jesus (Grand Rapids: Baker Book House, 1991), xiii.

${ }^{3}$ Ibid.

${ }^{4}$ Lih. Alkitab (Jakarta: Lembaga Alkitab Indonesia, 1993), 105; The Holy Bible, New International Version, 780; New Geneva study Bible, 1995, 1639.

${ }^{5}$ E.E. Ellis, The New Century Bible Commentary, The Gospel of Luke (Grand Rapids: Eerdmans, 1991), 212; Craig A. Evans, New International Biblical Commentary, Luke (Peabody, Massachusetts: Hendrickson Publishers, 1993), 266; Herbert Lockyer, The Parables of the Bible (Grand Rapids: Zondervan, 1963), 298; William Barclay, Pemahaman Alkitab Setiap Hari (Jakarta: BPK Gunung Mulia, 1996), 325; B.J. Boland, Tafsiran Lukas 9:51-24:53 (Jakarta: BPK Gunung Mulia, 1982 ), 159; Kistemaker, The Parables of..., 249; Bock, Baker Exegetical Commentary..., 1444. 
Menurut pendapat penulis, bahwa penekanan pada karakter dalam perumpamaan memang adalah sangat penting untuk menentukan one main point, namun demikian, penulis lebih setuju untuk melihat secara bersama kedua karakter dalam perumpamaan ini, yaitu hakim dan janda, sehingga judul perumpamaan ini bisa dinamakan ketekunan seorang janda atau hakim yang tidak benar. Bagi penulis kedua karakter ini adalah sama penting. Dan walaupun penulis melihat secara bersama dua karakter ini, namun hanya ada one main point of the parable, yaitu doa. Pokok utama ini adalah berdasarkan maksud perumpamaan (18:1), peran kedua karakter, dan konteks pengajaran Yesus mengenai doa sebagai satu bagian dari pemuridan (discipleship in the kingdom context).

\section{Struktur Teks}

Memang ada baiknya menemukan sendiri struktur teks dari teks asli, namun penulis mempertimbangkan beberapa struktur yang telah disediakan oleh beberapa ahli. Seperti E.E. Ellis mengemukakan struktur Lukas 18:1-8 sebagai berikut: Besides the introduction (ay 1), the passage consists of a parables (ay 2-5) with a double conclusion (ay 6-8). ${ }^{6}$ Dan Darrell L. Bock membuat struktur Lukas 18:1-8 sebagai berikut:

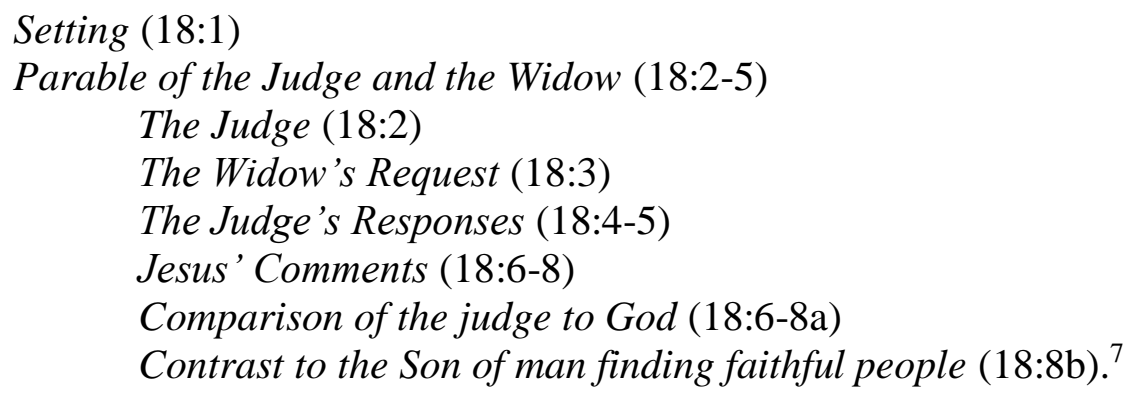

Dari dua bentuk struktur teks di atas, maka penulis lebih cenderung untuk mengikuti struktur dari Darrell L. Bock, namun dengan sedikit modifikasi pada bagian terankhir. Jadi, menurut penulis, struktur teks Lukas 18:1-8 adalah sebagai berikut:

Pendahuluan (18:1)

Objek Perumpamaan Yesus

Maksud dan Tujuan Perumpamaan

\footnotetext{
${ }^{6}$ Ibid.

${ }^{7}$ Bock, Baker Exegetical Commentary..., 1446.
} 


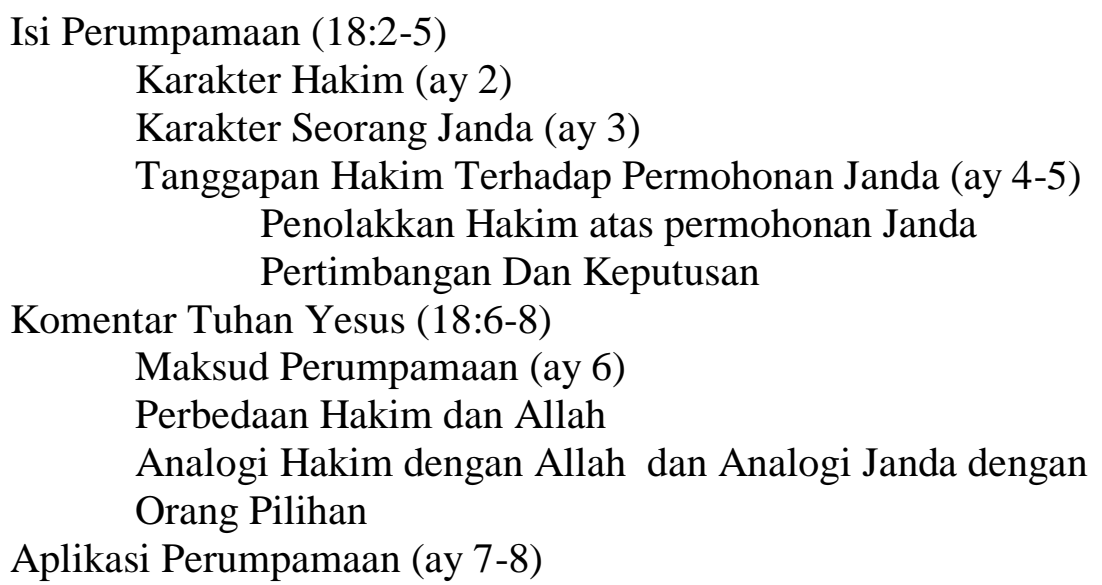

Struktur di atas ini akan menjadi kerangka penafsiran dan pembahasan penulis berikut ini. Sebelumnya, penulis memandang perlu untuk mengemukakan mengenai analisis latarbelakang teks, seperti pembahasan berikut ini.

\section{Analisis Latarbelakang Teks}

Ada pun latarbelakang Lukas menulis perumpamaan Yesus ini, berkenaan dengan tekanan yang dialami oleh orang Kristen dari pihakpihak non-Kristen. Searah dengan ini, E.E. Ellis mengungkapkan bahwa: Luke apparently is writing to a situation in which Christians under severe persecution are denying their faith. ${ }^{8}$ Karena itu, Lukas menulis bahwa dalam keadaan seperti ini, dan pada waktu kedatangan Tuhan, adakah Ia mendapati iman di bumi? (18:8). Dan lagi, dalam Lukas 12:11 diungkapkan tekanan yang dialami oleh orang percaya dari pihak-pihak majelis, pemerintah-pemerintah atau penguasa-penguasa.

Secara khusus, persoalan yang sedang dihadapi oleh pembaca pertama Injil Lukas, ialah masalah kedatangan Tuhan yang kelihatannya adalah ditunda-tunda. Bagi Gereja mula-mula, penundaan kedatangan Tuhan (the 'delay' of parousia) bukanlah suatu masalah kronologis melainkan sesuatu yang istimewa yang akan dialami orang Kristen di balik penderitaan, ketahanan bahkan kematian karena iman. E.E. Ellis berkomentar sebagai berikut:

From the first this had a simple and effective answer (20:37, I Th 4:13). It was not delay qua delay but delay in the face of continuing

${ }^{8}$ Ellis, The New Century Bible..., 212. 
death under persecution that caused hope to fade and apostasy to rise. 'Sunshine' delay poses no problem. But a thousand years go by in one short hour waiting for the lions. ${ }^{9}$

Dengan demikian, latarbelakang Lukas secara khusus teks 18:1-8 adalah mengenai konteks penderitaan orang-orang percaya karena iman yang mereka alami di bumi. Mereka memerlukan penguatan, dan Tuhan Yesus sebagai fokus dan sumber kekuatan iman di tengah-tengah penderitaan mengajarkan mengenai beriman dan berdoa seperti seorang janda yang menghadapi kemustahilan. Teks ini tidak sama dengan kecenderungan masa kini, bahwa iman dan doa terpisah dari penderitaan, sehingga iman dan doa menjadi alat untuk mengusir penderitaan, atau alat untuk menghimpun keberhasilan atau kesuksesan. Mari lanjutkan dengan menganalisis konteks untuk menemukan arti teks.

\section{Analisis Konteks}

Analisis konteks sangat penting untuk mengetahui maksud penulis menulis teks yang sedang kita pelajari. Berkenaan dengan itu, ada tiga konteks yang patut dianalisis berikut ini, yakni konteks Injil Sinoptis, konteks keseluruhan Injil Lukas, dan konteks dekat.

\section{Analisis Konteks Injil Sinoptis}

Perumpamaan tentang seorang janda yang tekun dalam Lukas 18:18 tidak ditemukan dalam teks Injil-Injil yang lain, kecuali hanya pada tulisan Lukas yang mencatat perumpamaan itu. Dengan kata lain, Para penulis Injil yang lain seperti Matius dan Markus tidak memasukkan atau mencatat perumpamaan Yesus tersebut dalam Injilnya. Karena itu, memahami Lukas 18, lebih tepat pada upaya memahami konteks keseluruhan Injil Lukas saja, seperti yang penulis kemukakan berikut ini.

\section{Konteks Keseluruhan Injil Lukas}

Kyu Sam Han membagi Injil Lukas dalam 7 Bagian besar, yaitu : ${ }^{10}$

Pasal 1- 2 : Infancy Narrative

Pasal 3-4:15

\section{: Baptism and Temptation}

${ }^{9}$ Ellis, The New Century Bible..., 212.

${ }^{10}$ Kyu Sam Han, "Catatan Kuliah," God's Saving Plan: A Redemptive Historical Interpretation of the Gospel of Luke (Pacet: ICTS , 1998 ). 


$\begin{array}{ll}\text { Pasal 4:16-9:50 } & \text { : Galilee Ministry } \\ \text { Pasal 9:51-19:27 } & \text { : Journey Narrative } \\ \text { Pasal 19:28-21 } & \text { : Ministry in Jerusalem } \\ \text { Pasal 22-23 } & \text { : Passion } \\ \text { Pasal 24 } & \text { : Resurrection and Ascension }\end{array}$

Dan menurut Bock bahwa: Luke records many parables, most as part of his emphasis on Jesus' teaching in the 'journey to Jerusalem' section (9:51-19:44). ${ }^{11}$ Dengan demikian, Lukas 18:1-8 adalah salah satu bagian dari Journey Narrative (9:51-19:27). Dalam bagian ini, Lukas memaparkan pengajaran Yesus tentang Kerajaan Allah. Dan discipleship (pemuridan) adalah bagian integral dari Pengajaran Yesus tentang Kerajaan Allah. Perumpamaan tentang seorang janda yang tekun (Luk 18:1-8), adalah memiliki persamaan dengan perumpamaan tentang seorang yang datang ke rumah temannya pada tengah malam (Luk 11:5-8). Lukas memberikan dua laporan yang sama, yaitu: yang pertama mengenai seorang laki-laki dan kedua adalah seorang wanita. Kedua cerita ini mengetengahkan pokok bahasan yang sama, yaitu: Keduanya meminta atau memohon dengan sikap tidak malu (Luk 11:8) dan sikap memohon dengan tidak jemu-jemu atau memohon dengan terus-menerus (Luk 18:2); Keduanya menjelaskan mengenai kepastian mengenai adanya jawaban bagi doa. Kedua teks di atas memang mendukung ciri khas penekanan Injil Lukas yaitu doa. Hal ini ditulis juga oleh Kyu Sam Han bahwa:

\begin{abstract}
Preyer is a characteristic emphasis of the Third Gospel. The Gospel opens with God's people at prayer (1:10) and closes with the believers jayfully blessing God in the temple (24:53). A survey of the prayer terminology used in Luke-Acts suggests that the theme of prayer is not unimportant. ${ }^{12}$
\end{abstract}

\title{
$\underline{\text { Analisa Konteks Dekat (Literary Context) }}$
}

Lukas 18:1-8 adalah teks yang tidak dapat dipisahkan dengan konteks dekat, yaitu teks sebelum dan sesudahnya. Perumpamaan tentang ketekunan seorang janda ini, masih dalam konteks pengajaran Yesus tentang kerajaan Allah yaitu berkenaan dengan jawaban Yesus atas pertanyaan orang-orang farisi (Luk 17:20). Pengajaran Yesus tentang kerajaan Allah ini diikuti dengan pengajaran Yesus tentang ketekunan

${ }^{11}$ Darrell, L. Bock, Baker Exegetical Commentary on the New Testament, Luke 1:1-9:50, Vol. 1 (Grand Rapids: Baker Books,1994), 947.

${ }^{12}$ Kyu Sam Han, "Prayer in the Gospel of Luke" in God's Saving Plan..., 1/7. 
dalam doa (Luk 18:1-8). Kemudian dilanjutkan dengan perumpamaan tentang orang farisi dan pemungut cukai yang masih mengetengahkan tentang doa (Luk 18:9-14).

Perumpamaan dalam Lukas 18:1-8, memang mengajarkan tentang doa. Dan berdasarkan konteks, perumpamaan ini adalah bagian penutup dari pengajaran Yesus tentang kerajaan Allah (Luk 17:20-37). Sebenarnya secara implisit, Yesus menyatakan bahwa diri-Nya adalah perwujudan sempurna kerajaan Allah yang sudah ada. Hal ini nampak dalam ungkapanNya bahwa "Sesungguhnya kerajaan Allah ada di antara kamu" (17:21). Namun konsep kerajaan Allah yang diajarkan oleh Tuhan Yesus adalah bersifat rohani, dalam arti tanpa tanda-tanda lahiriah (17:20b). Bahkan konsep kerajaan yang dipimpin oleh Raja yang menderita dan ditolak, yaitu konsep Anak manusia (Luk 17:25-26). Bersamaan dengan itu, Lukas juga membeberkan kondisi zaman Anak manusia ini adalah sama dengan kondisi yang terjadi pada zaman Nuh (17:26) dan zaman Lot (17:28). Untuk itu, kepada anggota kerajaan Allah, yaitu murid-murid-Nya pada waktu itu dan semua yang percaya kepada Tuhan Yesus, diharapkan untuk bertekun dan setia dalam iman sampai pada kedatangan Anak Manusia (Luk 18:8). Ketekunan iman anggota kerajaan Allah ini diungkapkan melalui berdoa dengan tidak jemu-jemu (tekun), doa pantang menyerah.

Perumpamaan tentang ketekunan seorang janda adalah ilustrasi Tuhan Yesus untuk menjelaskan dan menegaskan bahwa orang-orang pilihan Allah (18:7), murid-murid-Nya haruslah terlibat dalam pemuridan (discipleship). Dan doa adalah bagian dari pemuridan dalam konteks kerajaan Allah. Doa adalah untuk meningkatkan mutu rohani, supaya dapat bertahan dalam bahaya keduniawian yang membinasakan (Luk 17:22-29, bnd. Mat 24:40-42), dan sebagai kesiapan orang pilihan terhadap kedatangan Tuhan yang akan terjadi secara tiba-tiba atau tak terduga (Luk 17:30-37). Lukas memaksudkan perumpamaan ini untuk mendorong orangorang pilihan terus berdoa tanpa putus asa sebelum zaman akhir datang.

\section{EKSPOSISI LUKAS 18:1-8: BERIMAN DAN BERDOA KARENA KESETIAAN ALLAH}

Pandangan yang keliru bahwa dengan beriman, kita bisa beroleh kasih karunia Allah. Dengan berdoa kita beroleh kasih karunia Allah. Dengan beriman, kita beroleh berkat Allah. Dengan berdoa, Tuhan mengaruniakan berkat-Nya kepada kita. Iman dan doa seperti ini adalah iman dan doa dari orang-orang beragama bukan Kristen. Alkitab 
memberitahukan bahwa oleh karena kasih karunia Allah, kita beriman, maka kita bisa berdoa. Allah adalah sumber iman, alasan doa. Dalan teks ini, kesetiaan Allah adalah penyebab orang beriman dan berdoa.

\section{Pengantar}

Darrell Bock telah mengklasifikasi perumpamaan-perumpamaan yang ada dalam Injil Lukas termasuk Lukas 18:1-8 ini, adalah sebagai berikut: (1). Nama perumpamaan: Nagging Widow; (2). Topik perumpamaan: Future Spiritual life; (3). Tema perumpamaan: Prayer and Trust of God's Faithfulness. ${ }^{13}$ Pokok utama (main point) perumpamaan ini ialah mengenai Doa. Dan adanya perumpamaan ini merupakan ilustrasi dari pernyataan Yesus (Jesus' illustration of statement) tentang doa. Di awal teks ini (18:1), Lukas melaporkan dua hal yang penting, pertama yaitu objek perumpamaan, kedua yaitu maksud dan tujuan perumpamaan.

\section{Objek Perumpamaan Yesus (18:1)}

Lukas mencatat bahwa "Yesus mengatakan suatu perumpamaan kepada mereka" (ay 1). Istilah mereka tidak dijelaskan secara eksplisit dalam keseluruhan teks Lukas 18:1-8, namun untuk mengetahui mengenai siapa yang dimaksudkan oleh Lukas dengan istilah mereka, maka kita harus memperhatikan analisis konteks dekat, yaitu melihat ayat-ayat sebelumnya. Teks sebelumnya (17:20-37), Lukas melaporkan pengajaran Yesus tentang kedatangan kerajaan Allah. Dan Pengajaran ini bertolak dari pertanyaan orang-orang farisi tentang kerajaan Allah (17:20), namun sesunggunya, perumpamaan ini tidak ditujukan kepada orang-orang farisi, melainkan ditujukan kepada murid-murid-Nya. Hal ini sangat jelas dalam ungkapan "Dan Ia berkata kepada murid-muridNya" (17:22). ${ }^{14}$ Karena biasanya Yesus mengunakan perumpamaan untuk mengajar murid-murid-Nya. Berkenaan dengan pemakaian perumpamaan, Bock berpendapat bahwa: Jesus Himself used parables for instruction, exhortation and defence. ${ }^{15}$ Isi perumpamaan yang Yesus sampaikan kepada murid-murid-Nya dalam konteks ini, adalah tentang doa. Doa merupakan bagian dari pemuridan anggota-anggota kerajaan Allah setelah keputusan menerima Yesus.

\footnotetext{
${ }^{13}$ Bock, Baker Exegetical Commentary..., Vol.2, 949.

${ }^{14}$ Jesus is telling the parable "to them," (autois), which must look back to 17:22, where the disciples are the audience; Bock, Baker Exegetical Commentary..., Vol.2, 1446.

${ }^{15}$ Ibid., 947.
} 
Perumpamaan ini, merupakan ilustrasi Tuhan Yesus mengenai pengajaranNya yang masih berkenaan dengan kerajaan Allah (17:20-37).

\section{Maksud Dan Tujuan Perumpamaan (18:1)}

Seperti yang dikemukakan Bock bahwa: Keys to understanding a parable are direct speech, soliloquy, repetition, contrasts and the account's ending. ${ }^{16}$ Kunci ini sangat tepat untuk mengerti perumpamaan dalam Lukas 18:1-8. Karena dalam teks tersebut nampak perkataan langsung, kontras, dan catatan akhir yang ada di teks tersebut. Selain itu, bahwa berdasarkan teks, permulaan perumpamaan ini adalah sangat penting, karena selain memuat objek perumpamaan, juga memuat maksud dan tujuan perumpamaan. Sekalipun Kistemaker berpendapat: in Jesus' parables it is not the beginning of the story but the end that is important, ${ }^{17}$ namun berdasarkan teks, maka permulaan teks perumpamaan (Luk 18:1) adalah sangat penting untuk memahami keseluruhan perumpamaan itu (18:1-8).

Lukas mencatat bahwa Yesus mengatakan suatu perumpamaan kepada mereka untuk menegaskan, bahwa mereka harus selalu berdoa dengan tidak jemu-jemu. Dari ayat inilah keseluruhan perumpamaan dapat dipahami. Karena dalam ayat ini (18:1), nampak jelas maksud dan tujuan dari perumpamaan Yesus ini yaitu untuk menegaskan supaya murid-muridNya bertekun dalam doa. Lebih jauh, Sammers berkomentar mengenai maksud perumpamaan ini:

Luke indicates that Jesus' purpose in this parable was to encourage his disciples. In his prediction of the difficult experience thay faced in the future (17:22), he had given them cause for discouragement... He gave them this parable that they might see the importance of preyer and faithin opposition to losing heart in prolonged difficulty. ${ }^{18}$

Dalam NGSB tertulis: always ough to pray, tidak berarti berdoa dalam segala waktu atau terus-menerus (tak henti-hentinya), melainkan seperti pendapat Bock, yaitu praying again and again. ${ }^{19}$ Kalimat always ough to pray juga berkaitan dengan istilah egkakein, yang berarti to become

\footnotetext{
${ }^{16}$ Bock, Baker Exegetical Commentary..., Vol.2, 947.

${ }^{17}$ Kistemaker, The Parables of ..., xvi.

${ }^{18}$ Ray Summers, Commentary on Luke (Waco: Word Books, 1982), 206.

${ }^{19}$ Bock, Ibid., 1447.
} 
weary or tired, lose heart, dengan me berarti not lose heart..$^{20} \mathrm{Jadi}$, berdoa dengan tidak jemu-jemu yaitu berdoa dengan tidak menjadi lelah atau berdoa dengan tidak putus-asa. Berdoa dengan berulang-ulang, penuh energi, tidak menjadi lelah, atau tidak menjadi berputus asa karena menunggu waktu yang lama. Kita mungkin langsung menanggapi dengan berpikir mengenai jaminan atau dasar yang harus dipegang untuk bertahan, untuk tidak putus asa, untuk terus menerus berdoa. Mari kita temukan jawabannya pada pembahasan berikut ini.

\section{Isi Perumpamaan (18:2-5)}

Setelah Tuhan Yesus menegaskan kepada murid-murid-Nya tentang berdoa dengan tidak putus asa dan berdoa secara berulang-ulang, maka kemudian, Ia mengilustrasikan ajaran-Nya itu dengan suatu perumpamaan. Ada Dua karakter yang menjadi sorotan dalam perumpamaan ini, yaitu pertama adalah karakter seorang hakim dan kedua adalah karakter seorang janda.

\section{Karakter Hakim (ay 2)}

Perumpamaan ini dimulai dengan membicarakan tentang seorang hakim dengan sifat-sifatnya yang buruk. Bahwa Hakim ini adalah seorang yang tidak takut akan Allah dan tidak menghormati seorang pun (ay 2). Ada komentar berkenaan dengan karakter hakim ini. Menurut Barclay:

Hakim jelas bukanlah seorang hakim Yahudi... Hakim ini adalah seorang dari hakim-hakim yang ditunjuk baik oleh Herodes atau pun oleh penguasa Romawi. Hakim-hakim demikian terkenal dengan nama buruknya. Kalau si penuntut tidak mempunysai pengaruh besar dan yang bersangkutan tidak mempunyai uang yang cukup untuk mempengaruhi para hakim, maka perkaranya tidak akan mendapat perhatian..$^{21}$

${ }^{20}$ Wesley J. Perschbacher, Refresh Your Greek (Chicago: Moody Press, 1989), 311; New geneva Study Bible (NGSB), (Nashville: Thomas Nelson Pub., 1995), 1639.

21 Alasan bahwa hakim tersebut bukanlah hakim Yahudi karena kalau hakim yahudi maka segala perselisihan hari-hari biasanya dibawa ke hadapan tua-tua, dan sama sekali tidak dibawa kepada pengadilan umum. Jika dibawah hukum Yahudi, suatu perkara dibawa ke pengadilan, maka satu orang saja tidak dapat merupakan suatu pengadilan. Selalu terdapat tiga orang hakim, yang seorang dipilih oleh pendakwa, yang seorang oleh terdakwa, dan yang seorang lagi yang tidak terikat dengan siapa-siapa; William Barclay, Pemahaman Alkitab setiap hari, Lukas ( Jakarta: BPK Gunung Mulia, 1983). 
Mulanya Bock berpendapat bahwa: the judge is probably a Jew and may have been a powerful man, since the Romans allowed the Jews to manage many of their own legal affairs, ${ }^{22}$ namun karena hakim ini digambarkan sebagai seorang yang tidak takut akan Allah, maka Bock pun menyimpulkan seperti pendapat Barclay, bahwa: He is possibly a political type of 'police' judge. ${ }^{23}$ Hakim seperti ini bukanlah hakim yang ideal yang seharusnya membela kaum miskin dan lemah, melainkan tipe hakim yang tidak memiliki belas kasihan, tidak takut Tuhan dan tidak menghormati sesama, karena itu Boch pun menulis lebih jauh: Neither the laws of God nor public opinion can stir his conscience. Appeal to this character would be difficult. ${ }^{24}$

\section{Karakter Seorang Janda (ay 3)}

Karakter yang kedua dari perumpamaan ini adalah seorang janda tanpa harapan, sekalipun ia belum terlalu tua. ${ }^{25}$ Janda ini percaya bahwa hakim tersebut adalah hakim yang bertanggung jawab. Karena itu, ia selalu datang kepada hakim tersebut. Begitu pula pendapat Summers bahwa: She recognized him as the right one to deal with her case. Because she felt the importance of her case, she found it necessary to go to the judge repeatedly to seek a just settlement. ${ }^{26}$ Janda ini berkata: "Belalah hakku terhadap lawanku." Janda mungkin sedang menghadapi sedikit kesulitan dengan keuangan sehingga tidak mampu membayar hakim tersebut, karena itu ia berkali-kali datang dan memohon kepada hakim untuk memberikan keadilannya. Kata datang (ercheto) dalam bentuk iterative imperfect dan dalam konteks ini, Bock berpendapat bahwa: iterative and suggests repeated appeals for aid. She seeks relief from the opponent who wronged her. ${ }^{27}$ Janda yang tanpa harapan, tidak berdaya itu memohon dengan berulang-ulang kepada seseorang yang memiliki wibawa dan kuasa untuk membelanya. Kata membela (ekdikeo) adalah dalam arti membenarkan dia, seperti ungkapan ekdikeso yang berarti membenarkan dalam ayat 5 .

\footnotetext{
${ }^{22}$ Bock, Baker Exegetical Commentary..., Vol.2, 1447.

${ }^{23}$ Bock, Baker Exegetical Commentary..., Vol.2, 1447.

${ }^{24}$ Ibid., 1448

${ }^{25}$ Since in this culture women married at age thirteen or fourteen and widows were frequently quite young; Ibid.

${ }^{26}$ Summers, Commentary on Luke..., 206.

${ }^{27}$ Bock, Ibid., 1448.
} 


\section{Tanggapan Hakim Terhadap Permohonan Janda ( ay 4-5)}

\section{Hakim Menolak Permohonan Janda Itu}

Beberapa waktu lamanya hakim itu menolak. Hakim tersebut tidak meresponi permohonan janda itu untuk beberapa waktu lamanya (epi chronon), seperti yang tertulis: As often as the widow came, he refused. ${ }^{28}$ Penolakkan yang dimaksud tidaklah digambarkan dengan sikap mengusir dengan kasar, melainkan tidak mengubrisnya atau tidak menjawab permohonan janda tersebut. Tentu tidak ada alasan untuk sikap itu, namun karena karakter hakim itu yang adalah tidak sensitif kepada kebutuhan orang dan tidak ada sesuatu dari janda tersebut yang dapat dianggap mempengaruhi hakim itu, maka jelaslah hakim itu menolak permohonan janda tersebut. Tidak ada kesalahan dengan permohonannya, namun masalahnya terletak pada hakim itu, yaitu tidak perduli kepada Janda itu.

\section{Pertimbangan dan Keputusan}

Teks selanjutnya tertulis: "Tetapi kemudian ia berkata dalam hatinya: Walaupun aku tidak takut akan Allah dan tidak menghormati seorangpun, namun karena janda ini menyusahkan aku, baiklah aku membenarkan dia, supaya jangan terus saja ia datang dan akhirnya menyerang aku." Jawaban atau tanggapan Hakim terhadap permohonan janda itu, bukan karena hakim itu menyadari tugas untuk menjalankan keadilan, melainkan karena pertimbangannya, bahwa janda itu terus mengganggu dia, dan bahaya yang nantinya akan menyerang dia secara membabi-buta. ${ }^{29}$ Penekanan yang pantas dalam ayat 4-5 yaitu pada keputusan hakim yang membenarkan janda itu dan ketekunan janda dalam berdoa. Hal ini sama dengan perumpamaan tentang seorang yang datang ke rumah temannya pada tengah malam. Dan karena sikap yang tidak tahu malu dari orang itu, maka temannya itu akan bangun juga dan memberikan kepadanya apa yang diperlukannya (Luk 11:7-8). Apalagi Bapa yang di sorga, Ia akan memberikan kepada mereka yang meminta kepada-Nya. Berkenaan dengan itu, Sammers berkomentar: the central teaching is not

${ }^{28}$ Bock, Baker Exegetical Commentary..., Vol.2, 1448.

${ }^{29}$ Dan siapa tahu, begitulah pikirnya, kalau itu nanti menjadi mata gelap sehingga ia menyerang saya dan memukul mukaku biru lebam (kata-kata dari ay. 5b itu dipinjam dari permainan tinju); B.J. Boland, Tafsiran Lukas 9:51-24:53. II (Jakarta: BPK Gunung Mulia, 1982), 161. 
that man can, by repeated prayer, break down the will of God. It is rather that man can be encouraged in prayer by the realization that he prays to a just God who desires to give and to do that which his child needs. ${ }^{30}$

Jadi, fokus utama perumpamaan ini bukan pada karakter dan pertimbangan hakim itu, melainkan kepada keputusan hakim yang membenarkan dan kepada ketekunan janda tersebut. Ketekunan janda tersebut nampak dalam beberapa keterangan dari teks perumpamaan itu sendiri, bahwa "walaupun permohonan janda tersebut ditolak berkali-kali, dimana sesering janda itu datang dan memohon, sesering itu juga janda tersebut ditolak." Inilah bukti ketekunan janda tersebut. Begitu juga dengan ungkapan hakim bahwa "karena janda ini menyusahkan aku,... supaya jangan terus saja ia datang" kalimat ini menerangkan dengan jelas mengenai ketekunan janda tersebut. The woman's constant intercession has brought success. Here is the example that the disciples' prayer should emulate. ${ }^{31}$ Teks ini sangat menonjolkan mengenai ketekunan Janda yang terus menerus datang kepada hakim.

\section{Komentar Tuhan Yesus Mengenai Perumpamaan Ini (ay 6)}

Setelah Lukas menyampaikan perumpamaan tentang hakim yang tidak benar atau ketekunan seorang janda, maka kemudian Lukas menindak-lanjuti dengan komentar Tuhan Yesus sendiri.

Kata Tuhan "Camkanlah apa yang dikatakan hakim yang lalim itu!" (18:6). Listen to what the unjust judge says (NIV) - Hear what the unjust judge said (NGSB). Kata camkanlah (listen) adalah searah dengan maksud perumpamaan ini, yaitu untuk menegaskan ajaran tentang doa (18:1). Kalimat "camkanlah apa yang dikatakan hakim yang lalim itu" adalah komentar Tuhan Yesus. Komentar itu secara khusus berfokus kepada perkataan hakim yang dianalogikan dengan Allah. Berkenaan dengan itu, Kistemaker berkomentar sebagai berikut:

He wants the disciples to pay attention to the very words of the judge. They are important for a correct understanding of the parable. As in the parable of the friend at midnight Jesus uses the rule of contrasts. He contasts the worst in man to the best in God:

"This is what the unjust judge says and does." 32

${ }^{30}$ Summers, Commentary on Luke..., 207.

${ }^{31}$ Bock, Baker Exegetical Commentary..., Vol.2, 1450.

${ }^{32}$ In the parables of the unjust judge, Jesus is more specific than in the one of the friend at midnight. In fact, the interpretation and application of the massage of the 
Sekali lagi, komentar Tuhan tentang hakim itu, bukan mengenai karakter hakim yang jelas adalah buruk, melainkan perkataan dan tindakan hakim itu yang adalah kebenaran analogis dengan kebenaran Allah.

\section{Perbedaan Antara Hakim Dan Allah (ay 6-7)}

Ada dua pribadi yang dianalogikan dalam Lukas 18:6-7, yaitu hakim dan Allah, namun sebelum kita memperhatikan analogi tersebut, maka terlebih dahulu kita memperhatikan perbedaan-perbedaan yang sangat menyolok dari keduannya. Berdasarkan teks, Kistemaker melihat perbedaan antara hakim dan Allah yaitu:

\section{Pertama}

Tidak ada hubungan yang mendasar antara janda dan hakim, apakah itu hubungan sosial, bersifat umum, bersifat keagamaan. Hakim ingin menghindar dari janda itu, bahkan ia menghendaki hubungan dengan janda tersebut sebagai lawyer client-nya akan berakhir. Namun hakim yang lalim itu mendengarkan janda tersebut dan membenarkannya.

\section{Kedua}

Allah telah memilih umat kepunyaan-Nya. Ia memiliki ketertarikan yang khusus kepada mereka karena mereka kepunyaan-Nya. Ketika umat-Nya berseru siang dan malam, Allah mengangkat kasus mereka dan membawa keadilan. Demikian dengan janda yang berseru kepada Allah, menerima keadilan, karena Allah mendengar dan menjawab doa. ${ }^{33}$

parables in Luke 11:5-8 must be gleaned from the general contex, while the parable of the unjust judge contains both the message and the application; Kistemaker, The Parables of..., 252.

${ }^{33}$ Moreover, no relationship exixts between the widow and the judge, whether is be social, communal, or religious. The judge wants to be rid of her so that even the lawyerclient relationship will end. And yet this unscrupulous judge listens to this widow and does her justice. By contrast, God has chosen his own people. He has a special interest in them because they belong to him. When his people cry to him day and night, God takes up their case and brings about justice. Thus, should the widow cry out to God, she would receive justice, because God hears and answers prayer; Kistemaker, The Parables of..., 252. 
Kistemaker menyimpulkan bahwa: The Judge listened to the widow for the wrong reason: to get off his back. God listens to his people because he loves them and vindicates their cause. The judge acts selfishly; God acts in behalf of his people. ${ }^{34}$

Pada dasarnya, tidak ada kesamaan antara hakim yang lalim dengan Allah; tidak ada kesamaan karakter, karena karakter hakim adalah seorang yang lalim, tidak takut Tuhan dan tidak berbelas-kasihan; juga tidak ada kesamaan motivasi, motivasi hakim membenarkan janda adalah motivasi tidak benar/mementingkan diri sendiri, sedangkan Allah membenarkan umat pilihan-Nya karena kasih-Nya; tidak ada kesamaan hubungan antara hakim dalam relasinya dengan janda, dan hubungan Allah dalam relasinya dengan umat pilihan-Nya. Jadi, hakim dan Allah adalah kontras sama sekali, namun yang dianalogikan dari karakter hakim ini dengan Allah adalah seperti yang penulis kemukakan berikut ini.

\section{Analogi Hakim Dengan Allah dan Analogi Janda Dengan Orang Pilihan}

Karena perbedaan karakter, motivasi antara hakim dan Allah adalah sangat menyolok, dalam arti tidak ada kesamaan sedikit pun, maka analogi hakim dengan Allah hanya berdasarkan pada perkataan dan tindakan hakim yang membenarkan janda tersebut. Tuhan Yesus menganalogikan tindakan hakim yang membenarkan janda itu dengan tindakan Allah membenarkan orang-orang pilihan-Nya (18:6-7).

Lebih jauh lagi, Tuhan Yesus menganalogikan figur Hakim dalam ayat 6 dengan Figur Allah dalam ayat 7. Hal ini adalah identik dengan analogi Figur bapa dunia dalam Lukas 11:9-13. ${ }^{35}$ Memang sulit sekali untuk mengerti mengapa Tuhan Yesus menganalogikan hakim dengan Allah. Sebab tidak ada kesamaan sedikit pun antara hakim dan Allah (antimetafor). Barclay mengomentari bahwa perumpamaan ini tidak bermaksud untuk menyamakan Allah dengan hakim yang tidak adil itu; Allah sama sekali bertolak belakang dengan hakim yang tidak adil dan keadilan, maka

${ }^{34}$ Kistemaker, The Parables of..., 253.

${ }^{35}$ Jika Bapa duniawi yang jahat tahu memberi pemberian yang baik kepada anakanakmu, apalagi bapamu yang di sorga! Ia akan memberikan yang terbaik (Roh Kudus) kepada mereka yang meminta kepada-Nya (Luk 11:13). Begitu juga, jika Hakim yang jahat dapat membenarkan janda itu, tidakkah Allah akan membenarkan orang-orang pilihan-Nya yang siang-malam berseru kepada-Nya? (Luk 18:7). Verses 7-8a clarify how the parable relates to God; Craig A. Evans, New Internation Biblical Commentary Luke (Peabody: Hendrickson Publishers, 1990 ), 266. 
apalagi Allah, yang memang adalah Bapa yang mengasihi, akan memberikan kepada anak-anak-Nya apa yang mereka inginkan. ${ }^{36}$ Dan berdasarkan teks yang ada, maka analogi hakim dan Allah ini, hanyalah dapat dimengerti melalui analogi perbandingan. Bahwa jika Hakim itu dapat membenarkan janda tersebut, apalagi Allah. Sebab hakim itu adalah lalim, tidak takut Tuhan, tidak berbelas-kasihan, dan hakim itu tidak ada hubungan pribadi apa pun dengan janda; dibandingkan dengan Allah yang adalah penuh kasih dan yang pada hakekatnya mempunyai hubungan dengan orang-orang pilihan-Nya.

Secara implisit bahwa dalam ayat 6-7 ini, Tuhan Yesus menganalogikan janda yang dibenarkan oleh hakim dengan orang-orang pilihan yang dibenarkan oleh Allah. Janda itu adalah orang yang tidak berdaya secara politis, ekonomi dan sosial. Barclay menjelaskan bahwa: "Janda itu adalah lambang dari mereka semua yang miskin dan yang tidak berdaya. Jelas, bahwa ia tanpa uang atau apa pun, tidak mempunyai harapan untuk memenangkan perkara dari hakim yang seperti itu." 37 Kondisi janda yang seperti ini adalah dianalogikan dengan orang-orang pilihan. Menurut Marshall bahwa orang-orang pilihan ini ialah "orangorang yang telah mendengar panggilan Allah dan menjawabnya." 38 Dengan beberapa referensi bagian kitab yang lain Summers berkomentar bahwa orang-orang pilihan ialah a synonym for believers or christians. ${ }^{39}$ Bagian ini sangat menghibur dan menguatkan orang Kristen yang sedang menderita. Tidak ada kekuatan dari diri sendiri, namun sebagai orang pilihan, Allahlah yang bertindak. Allah yang menjamin orang pilihan-Nya, yang lemah, namun kekuatannya adalah pada Allah.

\section{Aplikasi Perumpamaan (7-8)}

Pada ayat 7 dan 8, Tuhan Yesus mengaplikasikan perumpamaan sesuai dengan maksud utama perumpamaan yaitu mengenai ketekunan orang percaya dalam hal berdoa. Ada beberapa hal yang penting diungkapkan dalam bagian terakhir ini, khususnya yang berkaitan dengan ketahanan atau ketekunan dalam berdoa, yaitu:

36 William Barclay, Pemahaman Alkitab Setiap Hari, Lukas (Jakarta: BPK Gunung Mulia, 1996 ), 327.

${ }^{37}$ Barclay, Ibid., 326.

${ }^{38}$ I.H. Marshall, "Luke" in Donald Gutrie, Tafsiran Alkitab Masa Kini 3, MatiusWahyu (Jakarta: Yayasan Komunikasi Bina Kasih, 1990 ), 246.

${ }^{39}$ Summers, Commentary on..., 207. 


\section{Kepastian Jawaban Atas Doa}

Setelah Tuhan Yesus mengarahkan perhatian kepada hakim (ay 6), kemudian, Ia segera mengalihkan perhatian kepada Allah (ay 7). Kalau hakim itu telah bertindak yang bersifat kontradiksi dengan pribadi hakim itu sendiri, yaitu membenarkan janda, apalagi Allah. Inilah bahasa analogi perbandingan. Earle menjelaskan hal ini: If an unjust judge would finally surrender to persistent pleading, how much more would a faithful God of love avenge his elect. Hal yang sama dijelaskan juga oleh Leon Morris. ${ }^{40}$ Pertanyaan-pertanyan berikut, "Tidakkah Allah akan membenarkan orangorang pilihanNya yang siang malam berseru kepada-Nya? Dan adakah Ia mengulur-ulur waktu sebelum menolong mereka? (ay 7)," sesungguhnya mengungkapkan mengenai kepastian jawaban doa atas doa umat pilihan Tuhan. Berkenaan dengan itu, ada tiga pokok yang dibahas secara khusus, yakni tindakan Allah yang membenarkan, dengan segera, dan ketekunan orang-orang pilihan dalam berdoa.

\section{Tindakan Allah yang Membenarkan}

Kalimat "Tidakkah Allah akan membenarkan orang-orang pilihanNya" adalah pernyataan negatif Tuhan Yesus untuk menegaskan bahwa Allah pasti membenarkan orang-orang pilihan-Nya. Istilah membenarkan dalam teks Yunani adalah ekdikesin yang berarti vengeance, punishment; dengan objek langsung dari kata poiese, yang berarti menyebabkan keadilan dilakukan. ${ }^{41}$ Dalam bentuk kata kerja ekdikeo dipakai juga dalam pasal 18 ayat 3 dan 5, dimana Allah akan membawa keadilan kepada umat yang sedang menghadapi kesulitan. ${ }^{42}$ Bock menghubungkan hal ini dengan musuh-musuh Kristen, dengan berkata: He will judge those who persecute the righteous. ${ }^{43}$ Allah akan menjawab seruan umat-Nya dalam menghadapi pelbagai tekanan. Dalam hal ini, Allahlah yang aktif dalam karya

${ }^{40}$ Ralph Earle, The Wesleyan Bible Commentary (Grand Rapids: Eerdmans, 1964), 308; Since even an unjust judge can sometimes do justice, much more must we expect that righteous God will vindicate his elect; Leon Morris, Tyndale New Testament Commentaries, The Gospel According to St. Luke (Grand Rapids: Eerdmans, 1982), 263; Bnd. Since (1). He is not an unjust, but a righteous judge, and (2). The supplicant is not a stranger, but His own elect; J. Willcocok, The Preacher's Complete Homiletic Commentary on the Gospel According tp St. Luke (Grand Rapids: Baker Book House, 1978), 485.

${ }^{41}$ Perschbacher, Refresh Your..., 312.

42 Bock, Baker Exegetical Commentary ..., Vol.2, 1451.

43 Ibid. 
membenarkan atau menjawab doa umat pilihan-Nya yang sedang dalam kesulitan. Tindakan Allah ini lahir dari kasih-Nya, dan kasih-Nya ini dalam relasinya dengan orang-orang pilihan-Nya. ${ }^{44}$ Frase "orang-orang pilihan" (eklekton) dijelaskan oleh Bock sebagai berikut:

The term eklektos is a colletive (the only such time in Luke - Acts, though the singular is applied to Jesus in Luke 23:35; elsewhere in term has a traditional flavor, since so many other authors use it (Rom.8:33; 16:13; Col. 3:12; 1 Tim 5:21, 2 Tim 2:10; Titus 1:1; 1 Pet.1:1; 2:4,6,9; 2 John 1,13, Rev.17:14... The uses in 1 Peter, Colossians, and Romans share the collective overtones of this text, with Peter using OT imagery. God will come to the defense of his chosen people... ${ }^{45}$

Pemilihan adalah satu kebenaran yang paling dalam dari Alkitab. Karena pemilihan merupakan "Tindakan kekal Allah di mana Ia dalam kesukaan kedaulatan-Nya dan tanpa memperhitungkan jasa atau kebaikan manusia memilih sejumlah orang untuk menjadi penerima dari anugerah khusus dan keselamatan kekal." ${ }^{46}$ Pemilihan ini ada dalam kekekalan Allah, sebelum dunia diciptakan. Pemilihan berdasarkan kerelaan kehendak-Nya (Ef 1:4-5). Pemilihan ini adalah tanpa syarat (Ef 2:8,10; 2Tim 2:21); tidak dapat ditolak (Mzm 110:3; Flp 2:13); bertujuan untuk keselamatan orang pilihan dan untuk kemuliaan Allah (Rm 11:7-11; 2Tes 2:13; Ef 1:6, 12,14).

Sebagaimana telah dikemukakan sebelumnya, bahwa orang pilihan yaitu orang yang percaya kepada Tuhan Yesus atau orang Kristen. Dan pemilihan inilah yang menjadi keistimewaan relasi Allah dengan orang percaya. ${ }^{47}$ Pemilihan ini jugalah yang menjadi dasar yang pasti akan jawaban doa orang percaya.

\footnotetext{
${ }^{44}$ God listens to his people becaiuse He loves them; Kistemaker, The Parables of..., 253.

45 Bock, Ibid., 1451.

${ }^{46}$ Louis Berkhof, Teologi Sistematika. I (Jakarta: Lembaga Reformed Injili Indonesia, 1993), 207; J.C. Ryle, Expository Thoughts on Luke. 2 (Pennsylvania: The Banner of Truth Trust, 1986 ), 254-255.

47 Berbeda sama sekali dengan relasi hakim dan janda. Keduanya tidak ada hubungan apapun, namun Hakim itu menjawab atau membenarkan kasus janda tersebut. Dibandingkan dengan hubungan istimewa antara Allah dan orang pilihan, maka akan memberikan jaminan yang pasti mengenai jawaban Allah atas doa-doa umat pilihan-Nya.
} 


\section{Tindakan Allah yang Membenarkan Dengan Segera}

Pertanyaan kedua ialah "dan adakah Ia mengulur-ulur waktu sebelum menolong mereka ?" Pertanyaan ini pun merupakan jaminan akan adanya kepastian jawaban doa. Istilah mengulur-ulur (makrothumei) dalam bentuk present indikatif aktif -orang ketiga tunggal, yang berarti ia menunda, menunda lama. ${ }^{48}$ NGSB menterjemahkan pertanyaan kedua ini sebagai berikut: though He bears long with them? dan istilah bears long, diartikan: God will not keep putting them of like the judge in this parable; any delay will have a reason. ${ }^{49}$ Bagi Bock, pertanyaan ini dibuat sulit, karena Lukas tidak memakai baik kata kerja makrothumeo (to be patient) maupun kata benda makrothumia (patience). Ada banyak komentar berkaitan dengan hal ini. Namun menurut Bock yang paling tepat ialah:

With better contextual support, many commentators hold that the idea of patience has to do with God's response: God will not delay...; A final view also treats the reference to patience as God's response, but sees it in terms of his restricting the enemies' power to persecute until the vindication...God is patient with his elect in lightening the intensity of their suffering until he comes. ${ }^{50}$

Karena itu Bock menyimpulkan bahwa: Whether his patience is reflected in acurrent care that culminates in ultimate deliverance or in keeping persecution from being too great is not certain..$^{51}$ Pokoknya yang jelas ialah Allah membenarkan umat-Nya dengan segera. Hal ini tidak disebabkan oleh apa pun selain dari tindakan Allah saja, dan tidak ada alasan apapun untuk menahan tindakan Allah yang membenarkan umatNya. Tindakan Allah membenarkan umat-Nya ini berbada dengan tindakan hakim yang membenarkan janda tersebut. Dimana hakim bertindak setelah sekian lama janda memohon, sebagaimana kebiasaan hakim yaitu mengulur-ulur waktu untuk maksud disogok kemudian bertindak. Allah tidaklah demikian. Karena itu, dua pertanyaan: "Tidakkah Allah akan membenarkan orang-orang pilihan-Nya, dan adakah Ia mengulur-ulur waktu?" langsung diikuti dengan jawaban dalam ayat 8 yaitu: "Ia akan segera membenarkan mereka." Inilah pertanyaan retoris Tuhan Yesus berkenaan dengan jawaban Allah, bahwa Allah akan dengan segera

${ }^{48}$ Perschbacker, Refresh Your..., 312.

${ }^{49}$ New Geneva Study Bible (Nazhville: Thomas Nelson Publ., 1995), 1639. "Will he keep putting them off." The Holy Bible NIV (New Jersey: International Bible Society, 1984), 781.

${ }^{50}$ Bock, Baker Exegetical Commentary..., Vol. 2, 1454.

${ }^{51}$ Ibid. 
membawa keadilan untuk umat pilihan-Nya. Hal ini semakin diperkuat dengan penggunaan istilah segera. Dimana Istilah segera (tachei) dapat diartikan: "dengan cepat, tanpa menunda, secara tidak disangka-sangka." 52 Inilah jaminan bagi doa umat Tuhan, yaitu adanya kepastian bahwa Tuhan akan segera bertindak.

\section{Ketekunan Orang-Orang Pilihan Dalam Doa}

Kepastian jawaban doa memang tergantung pada kehendak dan waktu Tuhan. Namun hal yang tidak dapat diabaikan juga ialah ketekunan orang percaya dalam berdoa. Seperti ungkapan: “... orang-orang pilihanNya yang siang malam berseru kepadaNya." Ungkapan mengekspresikan ide yang sama dengan perintah Tuhan yaitu: "bahwa mereka harus selalu berdoa dengan tidak jemu-jemu." 53 Inilah jaminan bagi doa umat Tuhan, yaitu adanya kepastian bahwa Tuhan akan segera bertindak. Hal ini searah dengan maksud utama perumpamaan ini, dimana menjelaskan bahwa orang percaya harus secara terus-menerus membawa kasus mereka di hadapan Allah melalui doa. Mereka harus selalu berdoa dengan tidak jemu-jemu ketika jawaban doa belum diberikan dengan segera. Kistemaker berpendapat bahwa: Jesus teaches the power of prayer. By word and example he demonstrates that God's children must pray day and night and not los heart. ${ }^{54}$ Demikian juga, Paulus berulang kali menasehatkan untuk berdoa secara terus-menerus (siang dan malam), seperti kepada jemaat di Tesalonika (3:10).

Ada dua pertanyaan berkenaan dengan kepastian atau jaminan atas doa umat Tuhan. Pertanyaan pertama, ialah: Apakah Allah akan membenarkan atau memberikan keadilan kepada umat-Nya (apakah Allah akan menjawab doa umat-Nya)? Kedua ialah: Apakah umat Allah harus lama menunggu doa-doa mereka dijawab? Terhadap pertanyaan ini, Tuhan Yesus memberikan komentar bahwa: "Ia akan segera membenarkan mereka." Berkenaan dengan ini, Kistemaker menegaskan bahwa:

${ }^{52}$ Tachei, dat. Sg. neut. Tachos, ous to, speed, quickness, swiftness, haste; prep. Phrase with en (adv. Sense), quickly, at once, without delay; Perschbacher, Refresh Your..., 312.

53 "Crying day and night," expresses the same idea as our Lord's injunction that "men ought always to pray." Herbert Lockyer, The parables of the Bible (Grand Rapids: Zondervan, 1963 ), 300.

${ }^{54}$ Kistemaker, The Parables of..., 253. 
God's people can rely on God's faithfulness. He is not like the unjust judge whose character could not be trusted...In contrast to the judge, God is not annoyed when his people cry out to him day and night. The hearing of prayers is not to be understood as God's relenting from a set determination not to answer. Rather, God answers prayer in his time and in accordance with his plan..$^{55}$

Jaminan inilah seharusnya mendorong umat Tuhan untuk berdoa dengan tekun, bukan karena isi doa pendoa, bukan karena doanya pendoa (sugesti).

\section{Kesetiaan Umat Tuhan Dan Kedatangan Anak Manusia}

Pertanyaan yang bersifat retorikal dari Tuhan Yesus dalam ayat 7 , bahwa Tidakkah Allah akan membenarkan...? Adakah Ia mengulur-ulur waktu sebelum menolong mereka? Secara langsung dijawab oleh Tuhan Yesus sendiri dengan kalimat: "Ia akan segera membenarkan mereka" (ay 8). Setelah itu, Tuhan Yesus membuat pernyataan kontradiksi, yaitu: "Akan tetapi, jika Anak Manusia itu datang, adakah Ia mendapati iman di bumi?" Dalam NGSB tertulis: Nevertheless, when the Son of Man comes, will he really find faith on the earth. Istilah nevertheless menunjukan pernyataan kontradiksi dengan pernyataan sebelumnya. Pada bagian sebelumnya, Tuhan Yesus memberikan jaminan atau kepastian dari pihak Allah yang akan menjawab doa, namun apakah Tuhan akan menemukan kesetiaan iman dari pihak umat-Nya? Leon Morris mengartikan kalimat "adakah Ia menemukan iman di bumi?" sebagai berikut: he is not suggesting that there will be no believers. He is saying that the characteristic of the world's people at that time will not be faith." Begitu juga komentar dari NGSB: "This does not mean that there will be no believers, but that faith will not be characteristic of all. ${ }^{56}$

Bagian sebelumnya (17:20-37), Lukas mengemukakan tentang kedatangan kerajaan Allah, yang berfokus pada kedatangan Anak Manusia di akhir zaman (17:22, 24, 26, 30). Dan setelah Lukas mencatat perumpamaan Tuhan Yesus tentang Hakim yang lalim atau janda yang tekun (18:1-8), maka akhir dari teks perumpamaan tersebut, Lukas melaporkan kembali perkataan Tuhan Yesus tentang Kedatangan Anak Manusia (18:8). Jadi sangatlah jelas, bahwa Doa yang diajarkan oleh Tuhan Yesus dalam bentuk perumpamaan adalah satu pola pemuridan orang

${ }^{55}$ Kistemaker, The Parables of..., 254.

${ }^{56}$ Morris, Tyndale New Testament Commentaries..., 263; New Geneva Study Bible ( NGSB), 1639. 
percaya supaya tetap setia dalam menantikan kedatangan Tuhan Yesus kedua kali. Ditegaskan oleh Kistemaker bahwa:

Of Jesus' promise to return, the believer can be sure. The other side of the coin is whether the believer will be faithful in his prayers. Will the followers of Jesus contunually pray for the coming of God's Kingdom (Matt 6:10; Luk 11:2), and the return of Christ (1 Cor 16:22; Rev.22:17,20)?... Jesus does the work entrusted to him. Will the believer, however, be faithful to Jesus by constantly communicating with him in prayer? And will there be faith that perseveres when he returns? ${ }^{57}$

Jadi, sementara menantikan kedatangan-Nya yang kedua kali Tuhan mengharapkan pada umat-Nya untuk bertekun dalam doa. Karena ketekunan dalam doa merupakan manifestasi dari iman.

\section{Rumusan Teologis Perumpamaan Lukas 18:1-8}

Karakter janda dalam perumpamaan ini merupakan representatif dari orang-orang pilihan Allah (orang percaya) yang sedang berada dalam dunia. Sekalipun tidak memiliki pengaruh politis, ekonomi, dan sosial, sehingga tidak diperhitungkan dunia (hakim yang lalim), namun mereka diperhatikan oleh Allah secara khusus dalam konteks pemuridan dengan prinsip-prinsip kerajaan Allah. Orang pilihan (orang percaya) yang memang hidup dengan prinsip-prinsip kerajaan Allah pastilah berbeda dengan prinsip-prinsip kerajaan dunia, dan itulah sebabnya mereka menderita. Penderitaan orang pilihan disebabkan oleh karena ketidakadilan dalam dunia. Dalam penderitaan karena ketidakadilan, Tuhan memberikan jaminan bahwa Ia pasti membenarkan atau memberikan keadilan kepada mereka. Jaminan inilah yang sesungguhnya menjadikan orang-orang pilihan bertekun dalam iman mereka kepada Tuhan, dan mengekpresikan ketekunan iman mereka melalui ketekunan atau ketahanan berdoa. Dalam hal ini, Tuhan adalah penyebab orang beriman dan berdoa. Tidak ada alasan atau dasar dari pendoa sehingga doanya terkabalkan, Tuhanlah subjek doa. Tidak seorang pun tahu bagaimana sebenarnya berdoa. Dialah yang sesunguhnya berdoa di dalam dan melalui kita. Melalui Roh Kudus, Ia memimpin kita berdoa sesuai dengan kehendak-Nya, seperti yang Paulus nyatakan sebagai berikut.

\footnotetext{
${ }^{57}$ Kistemaker, The Parables of..., 253.
} 
Roh Kudus menolong kita di dalam kelemahan kita, karena kita tidak tahu bagaimana sebenarnya harus berdoa, tetapi Roh sendiri berdoa untuk kita kepada Allah dengan keluhan-keluhan yang tidak terucapkan. Dan Allah yang menyelidiki hati nurani, mengetahui maksud Roh itu, bahwa Ia sesuai dengan kehendak Allah, berdoa untuk orang-orang kudus ( $\operatorname{Rm}$ 8:26-27). 